\title{
Bond Length Variations in Tetrahydrothiophene Solvates of the Coinage Metals. The Crystal Structure of Di- $\mu$-iodo- bis[bis(tetrahydrothiophene)copper(l)]
}

\author{
Bertil Norén $^{a, \star}$ and Åke Oskarsson ${ }^{b}$ \\ ${ }^{a}$ Inorganic Chemistry 1, Chemical Center, University of Lund, Box 124, S-221 00 Lund and ${ }^{\mathrm{b} D e p a r t m e n t}$ of \\ Chemistry, University College of Sundsvall/Härnösand, Box 860, S-851 24 Sundsvall, Sweden
}

\begin{abstract}
Norén, B. and Oskarsson, $\AA .$, 1987. Bond Length Variations in Tetrahydrothiophene Solvates of the Coinage Metals. The Crystal Structure of Di- $\mu$-iodo-bis[bis (tetrahydrothiophene)copper(I)]. - Acta Chem. Scand., Ser. A 41: 12-17.

The crystal structure of $\left[\mathrm{Cu}\left\{\mathrm{S}\left(\mathrm{CH}_{2}\right)_{3} \mathrm{CH}_{2}\right\}_{2} \mathrm{I}\right]_{2}$ has been determined from X-ray intensity data collected at $200 \mathrm{~K}$ with a CAD 4 diffractometer. The space group is $P 2_{1} / n$ with $Z=4, a=10.629, b=10.577$ and $c=11.291 \AA, \beta=98.84^{\circ}$ and $V=1254.3 \AA^{3}$. The refinement converged to $R=0.059$. The compound is dinuclear with the two copper atoms joined by two iodo bridges. The coordination around the two copper atoms is not far from tetrahedral. The $\mathrm{Cu}-\mathrm{S}$ distances are 2.331 and $2.318 \AA$, and the $\mathrm{Cu}-\mathrm{I}$ distances 2.637 and $2.639 \AA$. The $\mathrm{Cu}-\mathrm{Cu}$ distance within the complex is remarkably short, $2.675 \AA$, and is only $0.11 \AA$ longer than in metallic copper; a weak metal-metal interaction cannot, therefore, be excluded. A survey of similar dinuclear $\mathrm{Cu}(\mathrm{I})$ halide compounds indicates that only I gives short $\mathrm{Cu}-\mathrm{Cu}$ distances, while $\mathrm{Cl}$ and $\mathrm{Br}$ give metal-metal distances in the range 3.03-3.35 $\AA$. A comparison of $\mathrm{M}-\mathrm{I}$ and $\mathrm{M}-\mathrm{S}$ distances in tetrahydrothiophene solvates of the coinage metals is made. Both distances have a very pronounced maximum for the $\mathrm{Ag}$ compound. The $\mathrm{Cu}-\mathrm{S}$ and $\mathrm{Au}-\mathrm{S}$ distances are the same $(2.32 \AA)$, while the Au-I $(2.57 \AA)$ is significantly shorter than the $\mathrm{Cu}$-I distance $(2.64 \AA)$. This is interpreted as a relativistic effect.
\end{abstract}

Geometrical parameters obtained for a series of related compounds may provide information of chemical interest. In a systematic study of differences in coordination properties of the $d^{10}$-ions $\mathrm{Cu}(\mathrm{I}), \operatorname{Ag}(\mathrm{I})$ and $\mathrm{Au}(\mathrm{I})$ we have synthesized the tetrahydrothiophene solvate iodides of these acceptors and determined their crystal structures. The structures of the gold and silver compounds have been reported previously. ${ }^{1,2}$ This paper reports the structure of $\left[\mathrm{Cu}(\mathrm{THT})_{2} \mathrm{I}\right]_{2}(\mathrm{THT}=$ tetrahydrothiophene).

\section{Experimental}

$\left[\mathrm{Cu}\left\{\widehat{\mathrm{S}\left(\mathrm{CH}_{2}\right)_{3} \mathrm{CH}_{2}}\right\}_{2} \mathrm{I}\right]_{2}$ was prepared at room temperature by treating copper foil with a solution of $\mathrm{I}_{2}$ in tetrahydrothiophene. Colourless crystals were formed at the surface of the metal. The copper content was determined electrogravimetri-

\footnotetext{
${ }^{*}$ To whom correspondence should be addressed.
}

cally (found $16.9 \%$; calc. $17.3 \%$ ) and the density from the loss of weight in cyclohexane (found $1.83 \mathrm{~g} \mathrm{~cm}^{-3}$; calc. $1.943 \mathrm{~g} \mathrm{~cm}^{-3}$ ). A single crystal with the dimensions $0.22 \times 0.28 \times 0.24 \mathrm{~mm}$ was used for data collection on a CAD 4 diffractometer employing monochromated $\mathrm{MoK \alpha}$ radiation $(\lambda=0.7107 \AA)$. Since the crystals lose tetrahydrothiophene at room temperature, all data were collected at $200 \mathrm{~K}$ with the aid of a $\mathrm{N}_{2}(\mathrm{~g})$ stream cooling device. Laue class and systematic extinctions are consistent with the space group $P 2_{1} / n$. Unit cell dimensions were obtained from $25 \theta$-values determined as $\theta_{h k l}=\left(\omega_{h k l}-\omega_{\overline{h k l}}\right) / 2$; $a=10.629(3), b=10.577(2)$ and $c=11.291(2) \AA$, $\beta=98.84(2)^{\circ}$ and $V=1254.3 \AA^{3}$. The intensities of 4476 reflections obeying $3 \leq \theta \leq 25^{\circ}$ were measured with the $\omega-2 \theta$ scan technique $\left(\Delta \omega=0.8^{\circ}+0.5^{\circ} \tan \theta\right)$. The scan interval was extended $25 \%$ at both ends for the background measurement. The ratio $\sigma(I) / I$ required in a scan was 0.028 and the maximum recording time

12 Acta Chemica Scandinavica A 41 (1987) 12-17 
STRUCTURE OF $\left[\mathrm{Cu}\left\{\widehat{\left(\mathrm{CH}_{2}\right)_{3}} \mathrm{CH}_{2}\right\}_{2}\right]_{2}$

Table 1. Positional and isotropic thermal parameters for the non-hydrogen atoms; e.s.d.'s in parentheses.

\begin{tabular}{lllll}
\hline Atom & $x / a$ & $y / b$ & $z / c$ & $U_{\text {iso }} \cdot 10^{2} / \AA^{2} a$ \\
\hline $\mathrm{Cu}$ & $0.57041(9)$ & $-0.00066(11)$ & $0.41149(10)$ & $3.37(4)$ \\
$\mathrm{I}$ & $0.46647(6)$ & $0.21107(6)$ & $0.47300(5)$ & $3.59(2)$ \\
$\mathrm{S} 1$ & $0.4958(2)$ & $-0.0458(2)$ & $0.2109(2)$ & $3.94(7)$ \\
$\mathrm{C} 11$ & $0.332(1)$ & $-0.099(1)$ & $0.209(1)$ & $6.1(4)$ \\
$\mathrm{C} 12$ & $0.248(1)$ & $0.013(1)$ & $0.177(1)$ & $7.0(5)$ \\
$\mathrm{C} 13$ & $0.306(1)$ & $0.086(1)$ & $0.088(1)$ & $6.5(4)$ \\
$\mathrm{C} 14$ & $0.448(1)$ & $0.103(1)$ & $0.133(1)$ & $4.9(3)$ \\
$\mathrm{S} 2$ & $0.7879(2)$ & $0.0346(2)$ & $0.4540(2)$ & $3.55(7)$ \\
$\mathrm{C} 21$ & $0.825(1)$ & $0.150(1)$ & $0.347(1)$ & $5.6(4)$ \\
$\mathrm{C} 22$ & $0.896(3)$ & $0.080(2)$ & $0.265(2)$ & $14.6(1.3)$ \\
$\mathrm{C} 23$ & $0.895(2)$ & $-0.048(2)$ & $0.270(1)$ & $8.4(6)$ \\
$\mathrm{C} 24$ & $0.861(1)$ & $-0.096(1)$ & $0.387(1)$ & $4.8(3)$ \\
\hline
\end{tabular}

${ }^{a} U_{\text {iso }}$ has been calculated from the average of the anisotropic temperature factors.

$120 \mathrm{~s}$. Three standard reflections were recorded at regular intervals; no systematic variations in their intensities were observed. $I$ and $\sigma(I)$ were corrected for Lorentz, polarization and absorption effects. The transmission factors evaluated by numerical integration varied from 0.396 to $0.516\left(\mu=44.6 \mathrm{~cm}^{-1}\right)$. Averaging symmetry-dependent reflections and excluding those with $I \leq 1.5 \sigma(I)$ resulted in 1716 reflections which were used in the calculations.

The structure was solved by vector and difference Fourier methods. The atomic parameters for the non-hydrogen atoms were refined using full matrix least-squares. The positions of the $\mathbf{H}$ atoms were calculated from geometrical criteria and were included in the structure factor calculations. Neither positional nor temperature parameters $\left(U_{\text {iso }}=0.08 \AA^{2}\right)$ were refined for the $\mathrm{H}$ atoms. The function minimized was $\Sigma w\left(\left|F_{\mathrm{o}}\right|-\left|F_{\mathrm{c}}\right|\right)^{2}$ with weights $w=\left[\sigma^{2} / 4\left|F_{\mathrm{o}}\right|^{2}+\right.$ $\left.\left(0.06\left|F_{\mathrm{o}}\right|\right)^{2}+0.5\right]^{-1}$. Scattering factors with corrections for anomalous dispersion were taken from Ref. 3. The final agreement indices $R=\Sigma$ $\left(\left|F_{\mathrm{o}}\right|-\left|F_{\mathrm{c}}\right|\right) / \Sigma\left|F_{\mathrm{o}}\right|$ and $R_{\mathrm{w}}=\left[\Sigma w\left(\left|F_{\mathrm{o}}\right|-\left|F_{\mathrm{c}}\right|\right)^{2 /}\right.$ $\left.\Sigma w\left|F_{\mathrm{o}}\right|^{2}\right]^{1}$ were 0.059 and 0.069 , respectively. A $\delta R$-plot resulted in an approximately straight line with slope 1.07 and intercept -0.07 . Computer programs used were those compiled and amended by Lundgren. ${ }^{4}$ Tables of $\left|F_{\mathrm{o}}\right|, \sigma\left(\left|F_{\mathrm{o}}\right|\right)$, $\left|F_{\mathrm{c}}\right|$ are available on request from the authors. The final positional parameters are given in Table 1 , and selected interatomic distances and angles in Table 2.
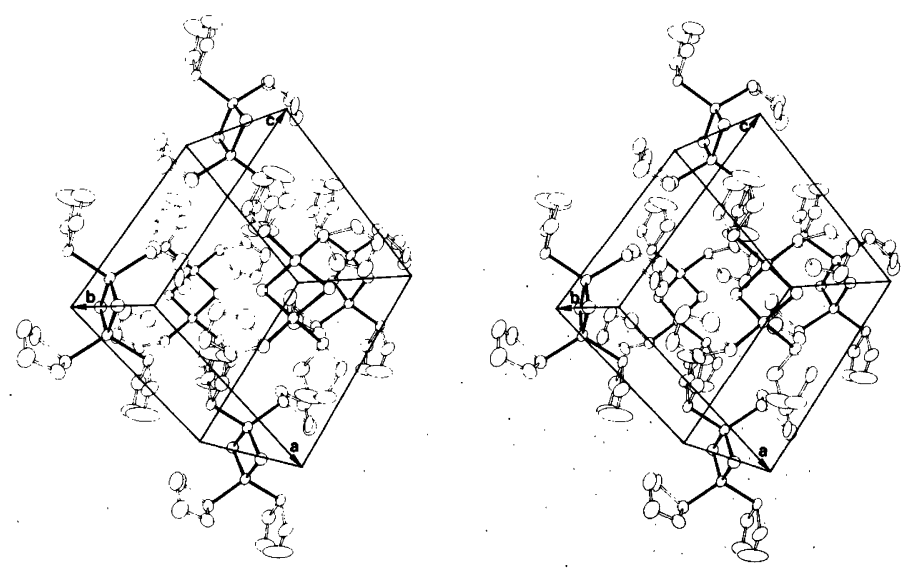

Fig. 1. Stereoscopic packing diagram of the unit cell contents. 
Fig. 2. Stereoscopic view of the bis(tetrahydrothiophene)copper(I) dimer showing atom labelling as identified in Tables 1 and 2. Hydrogen atoms are excluded for clarity.
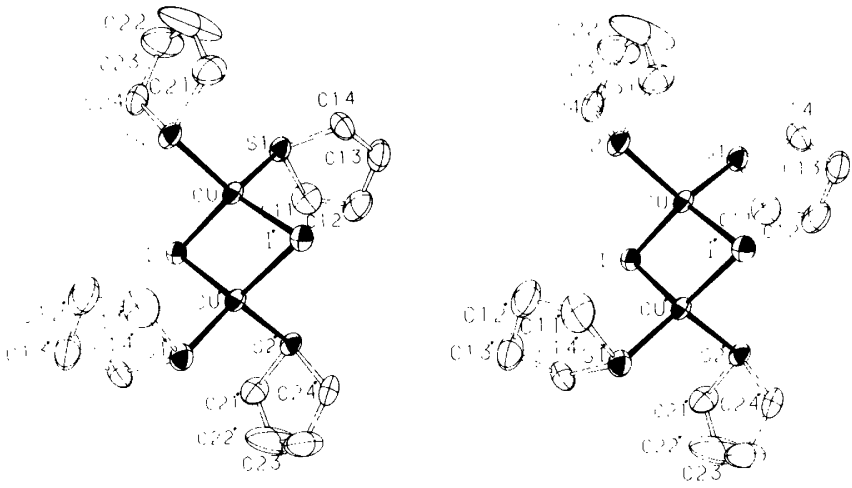

\section{Description of the structure}

The structure of $\left[\mathrm{Cu}\left\{\mathrm{S}\left(\mathrm{CH}_{2}\right)_{3} \mathrm{CH}_{2}\right\}_{2} \mathrm{I}\right]_{2}$ is composed of discrete molecules separated by van der Waals distances (Fig. 1). The molecule, which has a center of symmetry, is dinuclear with two copper atoms joined by two iodo bridges (Fig. 2). Each copper atom is further coordinated to two $\mathrm{S}$-atoms, giving a distorted tetrahedral coordination geometry around copper. The angles I$\mathrm{Cu}-\mathrm{I}^{\prime}$ and $\mathrm{S} 1-\mathrm{Cu}-\mathrm{S} 2$ are considerably larger than the tetrahedral value (Table $2 \mathrm{~A}$ ), resulting in a somewhat flattened tetrahedral geometry. The
$\mathrm{Cu}-\mathrm{Cu}$ distance (Table $2 \mathrm{~B}$ ) is only $0.11 \AA$ greater than the $\mathrm{Cu}-\mathrm{Cu}$ distance of $2.56 \AA$ in copper metal. ${ }^{5}$ Metal-metal interaction cannot be ruled out (vide infra) and it is justifiable to call this complex a cluster. The bonding around the $\mathrm{S}$ atoms is close to tetrahedral (Table 2C), as is also found in other THT solvates. ${ }^{1,2,6}$ The bond lengths and angles of the coordinated THT molecules (Table 2D) do not differ significantly from those found for the THT molecule in the gas phase. $^{7}$

Table 2. Selected bond distances $(\AA)$ and angles $\left(^{\circ}\right) .\left({ }^{\prime}\right): 1-x,-y, 1-z$.

A. Coordination geometry around the $\mathrm{Cu}$ atom

\begin{tabular}{|c|c|c|c|c|c|c|c|}
\hline $\begin{array}{l}\mathrm{Cu}-1 \\
\mathrm{Cu}-\mathrm{I}^{\prime}\end{array}$ & $\begin{array}{l}2.637(1) \\
2.639(1)\end{array}$ & $\begin{array}{l}\text { Cu-S1 } \\
\text { Cu-S2 }\end{array}$ & $\begin{array}{l}2.331(3) \\
2.318(2)\end{array}$ & $\begin{array}{l}\mathrm{I}-\mathrm{Cu}-\mathrm{S} 1 \\
\mathrm{I}-\mathrm{Cu}-\mathrm{S} 2 \\
\mathrm{~S} 1-\mathrm{Cu}-\mathrm{S} 2\end{array}$ & $\begin{array}{l}109.6(1) \\
104.7(1) \\
114.5(1)\end{array}$ & $\begin{array}{l}\mathrm{I}-\mathrm{Cu}-\mathrm{I}^{\prime} \\
\mathrm{S} 1-\mathrm{Cu}-\mathrm{I}^{\prime} \\
\mathrm{S} 2-\mathrm{Cu}-\mathrm{I}^{\prime}\end{array}$ & $\begin{array}{l}119.08(4) \\
104.7(1) \\
104.6(1)\end{array}$ \\
\hline
\end{tabular}

B. Intracluster parameters

$\begin{array}{lllr}\mathrm{Cu}-\mathrm{Cu}^{\prime} & 2.675(2) & \mathrm{Cu}-1-\mathrm{Cu}^{\prime} & 60.92(4) \\ \mathrm{I}^{\prime} \mathrm{I}^{\prime} & 4.548(1) & \mathrm{I}-\mathrm{Cu}-\mathrm{I}^{\prime} & 119.08(4)\end{array}$

C. Bond angles around the $S$ atoms

$\begin{array}{lrlr}\mathrm{C} 11-\mathrm{S} 1-\mathrm{Cu} & 104.7(4) & \mathrm{C} 21-\mathrm{S} 2-\mathrm{Cu} & 106.6(4) \\ \mathrm{C} 14-\mathrm{S} 1-\mathrm{Cu} & 108.7(3) & \mathrm{C} 24-\mathrm{S} 2-\mathrm{Cu} & 105.7(3) \\ \mathrm{C} 11-\mathrm{S} 1-\mathrm{C} 14 & 93.8(5) & \mathrm{C} 21-\mathrm{S} 2-\mathrm{C} 24 & 94.6(5)\end{array}$

D. Geometry of the tetrahydrothiophene molecules

\begin{tabular}{llllllll}
$\mathrm{S} 1-\mathrm{C} 11$ & $1.83(1)$ & $\mathrm{S} 1-\mathrm{C} 11-\mathrm{C} 12$ & $107(1)$ & $\mathrm{S} 2-\mathrm{C} 21$ & $1.81(1)$ & $\mathrm{S} 2-\mathrm{C} 21-\mathrm{C} 22$ & $106(1)$ \\
$\mathrm{C} 11-\mathrm{C} 12$ & $1.49(2)$ & $\mathrm{C} 11-\mathrm{C} 12-\mathrm{C} 13$ & $107(1)$ & $\mathrm{C} 21-\mathrm{C} 22$ & $1.47(3)$ & $\mathrm{C} 21-\mathrm{C} 22-\mathrm{C} 23$ & $118(2)$ \\
$\mathrm{C} 12-\mathrm{C} 13$ & $1.48(2)$ & $\mathrm{C} 12-\mathrm{C} 13-\mathrm{C} 14$ & $109(1)$ & $\mathrm{C} 22-\mathrm{C} 23$ & $1.35(2)$ & $\mathrm{C} 22-\mathrm{C} 23-\mathrm{C} 24$ & $112(1)$ \\
$\mathrm{C} 13-\mathrm{C} 14$ & $1.53(2)$ & $\mathrm{C} 13-\mathrm{C} 14-\mathrm{S} 1$ & $105(1)$ & $\mathrm{C} 23-\mathrm{C} 24$ & $1.52(2)$ & $\mathrm{C} 23-\mathrm{C} 24-\mathrm{S} 2$ & $107(1)$ \\
$\mathrm{C} 14-\mathrm{S} 1$ & $1.83(1)$ & $\mathrm{C} 14-\mathrm{S} 1-\mathrm{C} 11$ & $93.8(5)$ & $\mathrm{C} 24-\mathrm{S} 2$ & $1.80(1)$ & $\mathrm{C} 24-\mathrm{S} 2-\mathrm{C} 21$ & $94.6(5)$ \\
\hline
\end{tabular}




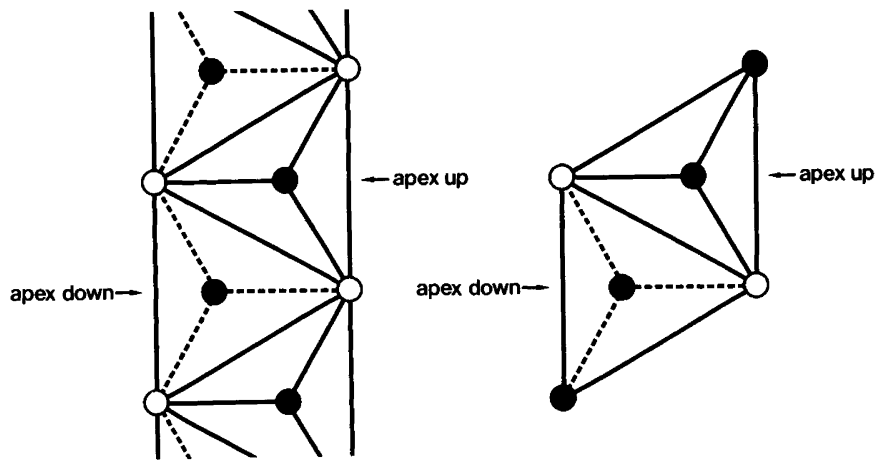

STRUCTURE OF [ $\left.\mathrm{Cu}\left\{\widehat{S\left(\mathrm{CH}_{2}\right)_{3} \mathrm{CH}_{2}}\right\}_{2}\right]_{2}$

Fig. 3. Schematic view of the $\left[\mathrm{Cu}\left(\mathrm{CH}_{3} \mathrm{CN}\right) \mathrm{X}\right]_{\infty}$ chain from which the dinuclear complex is cut out. $\mathrm{O}=\mathrm{I}^{-}$ and $\mathbf{Q}=$ donor atom of a solvate molecule.

\section{Discussion}

The structure of the dinuclear complexes with tetrahedral coordination around copper, $\left[\mathrm{CuL}_{2} \mathrm{X}\right]_{2}$ ( $\mathrm{X}=$ bridging halide and $\mathrm{L}=$ terminal group), is closely related to the chain structure of $\left[\mathrm{Cu}\left(\mathrm{CH}_{3} \mathrm{CN}\right) \mathrm{X}\right]_{\infty}$ (Fig. 3). This chain structure is related to the zinc blende structure adopted by $\mathrm{CuX}^{8.9}$ As is seen in Fig. 3, the dinuclear species may be regarded as a segment cut out of the chain, with two halides exchanged for two terminal groups. Table 3 gives some geometrical characteristics for the chain compounds $\left[\mathrm{Cu}\left(\mathrm{CH}_{3} \mathrm{CN}\right) \mathrm{X}\right]_{\infty}(\mathrm{X}=\mathrm{Cl}, \mathrm{Br}, \mathrm{I})$ and for some dinuclear species $\left[\mathrm{CuL}_{2} \mathrm{X}\right]_{2}$. A most striking fea- ture is the remarkably short $\mathrm{Cu}-\mathrm{Cu}$ distances in the dinuclear complexes with iodo bridges. With one exception, ${ }^{10}$ these $\mathrm{Cu}-\mathrm{Cu}$ distances are only $0.11-0.17 \AA$ larger than in copper metal. Small $\mathrm{Cu}-\mathrm{Cu}$ distances are attended by large $\mathrm{I}-\mathrm{Cu}-\mathrm{I}$ angles and $\mathbf{I} \cdots \mathbf{I}$ distances, since these quantities are interrelated. The fairly large metal-metal distance in the quinoline compound may be due to steric interference of the bulky quinoline ligands. ${ }^{10}$ The halides in the chain compounds may be regarded as close packed ${ }^{8}$ The I $\cdots$ I distances in the dinuclear complexes are $0.1-0.3 \AA$ longer than in $\left[\mathrm{Cu}\left(\mathrm{CH}_{3} \mathrm{CN}\right) \mathrm{I}\right]_{\infty}$, suggesting that the iodine atoms are well separated in the iodo-bridged

Table 3. The coordination geometry in some dinuclear $\mathrm{Cu}(\mathrm{I})$ halide solvates and their parent chain structures. $\mathrm{AN}=$ acetonitrile, MPY = 2-methylpyridine, $\mathrm{PY}=$ pyridine, FARS = dimethylphenylarsine, AFARS = o-dimethylaminophenyldimethylarsine, DIED $=N, N^{\prime}$-diisopropylethylenediamine, $\mathrm{QUI}=$ quinoline, $\mathrm{PHP}=$ triphenylphosphine.

\begin{tabular}{|c|c|c|c|c|c|c|}
\hline & {$[\mathrm{Cu}(\mathrm{AN}) \mathrm{Cl}]_{\infty}$} & {$\left[\mathrm{Cu}(\mathrm{MPY})_{2} \mathrm{Cl}\right]_{2}$} & {$\left[\mathrm{Cu}(\mathrm{FARS})_{2} \mathrm{Cl}\right]_{2}$} & {$[\mathrm{Cu}(\mathrm{AN}) \mathrm{Br}]_{\infty}$} & {$\left[\mathrm{Cu}(\mathrm{MPY})_{2} \mathrm{Br}\right]_{2}$} & {$[\mathrm{Cu}(\mathrm{PY})(\mathrm{PHP}) \mathrm{Br}]_{2}$} \\
\hline Ref. & 14 & 15 & 16 & 17 & 18 & 19 \\
\hline$X-X / A ̊$ & 3.72 & 3.76 & 3.67 & 3.99 & 3.96 & 4.09 \\
\hline $\mathrm{Cu}-\mathrm{Cu} / \AA ̊ \Omega$ & 3.04 & 3.15 & 3.03 & 3.05 & 3.35 & 2.95 \\
\hline Cu-X/Å & $2.41^{*}$ & 2.45 & 2.38 & $2.52^{*}$ & 2.59 & 2.53 \\
\hline $\mathrm{X}-\mathrm{Cu}-\mathrm{X} /{ }^{\circ}$ & $104.2^{\star}$ & 100.1 & 100.9 & $104.8^{*}$ & 99.6 & 108.5 \\
\hline \multirow[t]{2}{*}{$\mathrm{L}-\mathrm{Cu}-\mathrm{L}^{\circ}$} & - & 124.0 & 118.0 & - & 124.3 & 117.6 \\
\hline & {$[\mathrm{Cu}(\mathrm{AN})]_{x}$} & {$\left[\mathrm{Cu}(\mathrm{THT})_{2} \mathrm{l}\right]_{2}$} & {$\left[\mathrm{Cu}(\mathrm{PY})_{2} \mathrm{I}\right]_{2}$} & {$[\mathrm{Cu}(\text { AFARS }) !]_{2}$} & {$[\mathrm{Cu}(\mathrm{DIED})]_{2}$} & {$\left[\mathrm{Cu}(\mathrm{QUI})_{2} \mathrm{I}\right]_{2}(\mathrm{PY})$} \\
\hline Ref. & 8 & this study & 20 & 21 & 22 & 10 \\
\hline$X-X / \AA$ & 4.36 & 4.55 & 4.54 & 4.40 & 4.47 & 4.32 \\
\hline $\mathrm{Cu}-\mathrm{Cu} / \AA \AA$ & 3.01 & 2.68 & 2.70 & 2.73 & 2.73 & 3.14 \\
\hline CU-X/Å & $2.66^{\star}$ & 2.64 & 2.64 & 2.59 & $2.62^{*}$ & 2.67 \\
\hline $\mathrm{X}-\mathrm{Cu}-\mathrm{X} /{ }^{\circ}$ & $108.9^{\star}$ & 119.1 & 119.2 & 116.5 & $116.9^{\star}$ & 108.0 \\
\hline$L-C u-L^{\circ}$ & - & 114.5 & 100.9 & 82 & $82.9^{\star}$ & 118.5 \\
\hline
\end{tabular}

*Average value. 
dinuclear species. This is in contrast to the situation in dinuclear species with $\mathrm{Cl}$ or $\mathrm{Br}$ bridges. Here, the $\mathrm{X} \cdots \mathrm{X}$ distances are even smaller than those observed in the corresponding chain compounds. This is accompanied by large $\mathrm{Cu}-\mathrm{Cu}$ distances and small $\mathrm{X}-\mathrm{Cu}-\mathrm{X}$ angles. The $\mathrm{Cu}-\mathrm{Cu}$ distances are at least $0.47 \AA$ larger than in copper metal. In conclusion, iodide seems to be very effective in pulling copper atoms together in dinuclear complexes of this type. Hoffmann et al. ${ }^{11}$ have made extended Hückel calculations on the dinuclear species $\mathrm{M}_{2}(\mathrm{NO})_{4} \mathrm{X}_{2}$, where $\mathrm{M}$ is a $d^{10}$ ion and $\mathrm{X}=\mathrm{Cl}$ or $\mathrm{I}$. They conclude that there are three factors that influence the geometry and electronic structure: (1) the geometrical preference of the mononuclear fragment, (2) the opportunity for interaction offered by the orbitals of the bridging groups - "through-bond coupling", and (3) direct bonding or antibonding overlap of primarily metal-centered orbitals. In contrast to the situation prevailing for the complexes listed in Table 3, the calculated I-M-I angle is smaller $\left(86^{\circ}\right)$ than the tetrahedral angle and also smaller than the $\mathrm{Cl}-\mathrm{M}-\mathrm{Cl}$ angle $\left(88^{\circ}\right)$.

The situation for the tetranuclear complexes $[\mathrm{AgLX}]_{4}$, where $\mathrm{X}$ is a bridging halide, is similar to that for the dinuclear complexes discussed above. ${ }^{2}$ The chloro- and bromo-bridged tetranuclear species have large $\mathrm{Ag}-\mathrm{Ag}$ distances and could be described as having distorted cubane structures with $\mathrm{Ag}$ and $\mathrm{X}$ located at alternate corners of a cube. For iodo-bridged compounds the cubane structure is highly distorted, resulting in smaller $\mathrm{Ag}-\mathrm{Ag}$ distances. The coordination polyhedron is a star-like figure, a stella-quadrangula. The smallest $\mathrm{Ag}-\mathrm{Ag}$ distance is only $0.08 \AA$ larger than in silver metal. ${ }^{5}$ The ability of iodide to pull coinage metal ions together persists also when it is not acting as a bridging ligand. The compounds $\mathrm{Au}(\mathrm{THT}) \mathrm{X}(\mathrm{X}=\mathrm{Cl}, \mathrm{Br}, \mathrm{I})$ are composed of infinite arrays of gold atoms, which are not forced together by bridging ligands. ${ }^{1,12}$ The structures of the chloride and bromide species contain neutral complexes [Au(THT)X], with the gold atom linearly coordinating one $\mathrm{X}$ and one $\mathrm{S}$. The structure of the iodide complex is composed of alternating $\left[\mathrm{AuI}_{2}\right]^{-}$and $\left[\mathrm{Au}(\mathrm{THT})_{2}\right]^{+}$ions, both linear. The $\mathrm{Au}-\mathrm{Au}$ distances are 3.33 and $3.36 \AA$ in the chloride and bromide complexes, respectively, but only $2.98 \AA$ in the iodide. Again, the smallest $M-M$ distance in the iodide complex is in fact only $0.09 \AA$ larger than in the metal, ${ }^{5}$ as observed for both the tetranuclear $\mathrm{Ag}(\mathrm{I})$ and dinuclear $\mathrm{Cu}(\mathrm{I})$ species. Since appreciable metal-metal bonding certainly exists in $[\mathrm{Au}(\mathrm{THT}) \mathrm{I}]_{\infty}$, it may be inferred that metalmetal interactions persist also in $[\mathrm{AgLI}]_{4}$ and $\left[\mathrm{CuL}_{2} \mathrm{I}\right]_{2}$. It is thus justifiable to call the iodide compounds clusters.

The $\mathrm{M}-\mathrm{I}$ and $\mathrm{M}-\mathrm{S}$ distances in the series $\left[\mathrm{Cu}(\mathrm{THT})_{2} \mathrm{I}\right]_{2},[\mathrm{Ag}(\mathrm{THT}) \mathrm{I}]_{4}$ and $[\mathrm{Au}(\mathrm{THT}) \mathrm{I}]_{\infty}$ show a most remarkable maximum for the $\mathrm{Ag}$ compound: $\mathrm{M}-\mathrm{S}=2.32,2.55$ and $2.32 \AA$, and $\mathrm{M}-\mathrm{I}=2.64,2.90$ and $2.57 \AA$ for $\mathrm{Cu}, \mathrm{Ag}$ and $\mathrm{Au}$, respectively. ${ }^{1,2}$ The $\mathrm{Cu}-\mathrm{S}$ and $\mathrm{Au}-\mathrm{S}$ distances are about the same, while the Au-I is significantly smaller than the $\mathrm{Cu}-\mathrm{I}$ distance. This may be interpreted as a relativistic effect. For the heavier elements there is a relativistic contraction of the $s$ and $p$ orbitals and an expansion of the $d$ orbitals. ${ }^{13}$ This makes the $d$ orbitals extra prone to covalent bonding for heavier elements. The decrease from $\mathrm{Cu}$ to $\mathrm{Au}$ in the $\mathrm{M}-\mathrm{I}$ relative to the $\mathrm{M}-\mathrm{S}$ bond length indicates that iodine-centered $d$ orbitals are important in describing the bonding in these systems.

\section{References}

1. Ahrland, S., Norén, B. and Oskarsson, Å. Inorg. Chem. 24 (1985) 1330.

2. Norén, B. and Oskarsson, Å. Acta Chem. Scand., Ser. A 39 (1985) 701.

3. International Tables for X-Ray Crystallography, Kynoch Press, Birmingham 1974, Vol. 4.

4. Lundgren, J. O. Crystallographic Computer Programs, Report No. UUIC-B13-4-05, University of Uppsala, Uppsala 1982.

5. Wells, A.F. Structural Inorganic Chemistry, 5th ed., Clarendon Press, Oxford 1984.

6. Norén, B. and Oskarsson, A. Acta Chem. Scand., Ser. A 38 (1984) 479.

7. Nàhloská, Z., Nàhlovský, B. and Seip, H. M. Acta Chem. Scand. 23 (1969) 3534.

8. Nilsson, K. and Oskarsson, A. Acta Chem. Scand., Ser. A39 (1985) 663.

9. (a) NBS Circular 539 (1955) Vol. 4, p. 35; (b) Ibid. p. 36; Ibid. p. 37.

10. Hiller, W. Z. Naturforsch., Teil B39 (1984) 861.

11. Summerville, R. H. and Hoffmann, R. J. Am. Chem. Soc. 98 (1976) 7240.

12. Ahrland, S., Dreisch, K., Norén, B. and Oskarsson, A. To be published.

13. Pyykkö, P. and Desclaux, J.-P. Acc. Chem. Res. 12 (1979) 276. 
14. Massaux, M., Bernard, M. J. and LeBihan, M.T. Bull. Soc. Fr. Mineral Cristallogr. 92 (1969) 118.

15. Hiller, W. Acta Crystallogr., Sect. C 42 (1986) 149.

16. Gill, J.T., Mayerle, J.J., Welcker, P.S., Lewis, D. F., Ucko, D. A., Barton, D. J., Stewens, D. and Lippard, S. J. Inorg. Chem. 15 (1976) 1155.

17. Massaux, M. and Bernard, M. J. Acta Crystallogr., Sect. B 27 (1971) 2419.

18. Schramm, V., Pierce, A. and Hiller, W. Acta Crystallogr., Sect. C 40 (1984) 1840.
19. Zukerman-Schpector, J., Castellano, E. E., Mauro, A. E. and Roveri, M. R. Acta Crystallogr., Sect. C 42 (1986) 302.

20. Dyason, J. C., Engelhardt, L. M., Healy, P. C. and White, A. H. Aust. J. Chem. 37 (1984) 2201.

21. Graziani, R., Bombieri, G. and Forsellini, E. $J$. Chem. Soc. A (1971) 2331.

22. Haitko, D. A. J. Coord. Chem. 13 (1984) 119.

Received July 8, 1986. 